\title{
Echocardiographic assessment of left ventricular function in thyrotoxicosis and implications for the therapeutics of thyrotoxic cardiac disease
}

This article was published in the following Dove Press journal:

Therapeutics and Clinical Risk Management

5 February 2015

Number of times this article has been viewed

\author{
Raphael C Anakwue ${ }^{1,2}$ \\ Basden J Onwubere ${ }^{2}$ \\ Vincent Ikeh² \\ Benedict Anisiuba ${ }^{2}$ \\ Samuel $\mathrm{Ike}^{2}$ \\ Angel-Mary C Anakwue ${ }^{3}$ \\ 'Department of Pharmacology \\ and Therapeutics, ${ }^{2}$ Department \\ of Medicine, ${ }^{3}$ Department of \\ Radiography and Radiological \\ Sciences, Imaging Unit, College of \\ Medicine, University of Nigeria, \\ Nsukka, Enugu State, Nigeria
}

\begin{abstract}
Introduction: Thyrotoxicosis is an endocrine disorder with prominent cardiovascular manifestations. Thyroid hormone acts through genomic and non-genomic mechanisms to regulate cardiac function. Echocardiography is a useful, non-invasive, easily accessible, and affordable tool for studying the structural and physiological function of the heart.

Aim: We studied thyrotoxicosis patients in a Nigerian Teaching Hospital and employed trans-thoracic echocardiography to find out if there were abnormalities in the hearts of these patients.

Methods: Fifty adult thyrotoxicosis patients diagnosed with clinical and thyroid function tests in the medical out-patient unit of the hospital were recruited and we performed transthoracic echocardiography with a Sonos 2000 HP machine.

Results: We documented the presence of abnormalities in the following proportion of thyrotoxicosis patients: left ventricular enhanced systolic function in $30 \%$, enhanced diastolic function in $34 \%$, diastolic dysfunction in $34 \%$, heart failure with preserved ejection fraction in $10 \%$, heart failure with reduced ejection fraction in $6 \%$, and left ventricular hypertrophy in $34 \%$.

Conclusion: Echocardiography was useful in the stratification of cardiac function abnormalities and is indispensable as a guide in the choice of therapeutic options in patients with thyrocardiac disease. The finding of left ventricular enhanced systolic and diastolic functions signify early echocardiographic detectable cardiac abnormalities in thyrotoxicosis, and the clinical management includes the use of anti-thyroid drugs and $\beta$-adrenoceptor blockade. Diastolic dysfunction in thyrotoxicosis patients asymptomatic for cardiac disease should be treated with anti-thyroid drugs, and $\beta$-adrenoceptor blockade. The judicious application of clinical therapeutics will guide the use of anti-thyroid drugs, diuretics, digoxin, angiotensin inhibitors, and $\beta$-adrenoceptor blockade in the successful management of thyrotoxicosis patients with heart failure and reduced, preserved, or increased ejection fraction: parameters which are derived from echocardiography.
\end{abstract}

Keywords: thyrotoxicosis, left ventricle, echocardiography, therapeutics, thyrocardiac disease

\section{Introduction}

Thyrotoxicosis is the syndrome resulting from an excess of circulating free thyroxine and free triiodothyronine. ${ }^{1}$ When thyrotoxicosis is associated with thyroid gland overactivity, hyperthyroidism is said to occur. However, thyrotoxicosis can occur without hyperthyroidism when stored hormone is released from a damaged thyroid gland (eg, sub-acute thyroiditis, post-partum thyroiditis, amiodarone-induced thyroiditis) or when excess thyroid hormone is taken. ${ }^{1}$ In 1935 Robert Graves, an Irishman, and in 1940 Karl Adolph van Basedow, a German, separately described Basedow-Graves'
Department of Pharmacology an Therapeutics, College of Medicine, University of Nigeria, Enugu Campus, Ituku Ozalla, PMB 0I I29, Enugu State, Nigeria

$\mathrm{Tel}+2348033343044$

Email dranakwue@yahoo.com 
or Graves' disease which is now responsible for $70 \%-80 \%$ of all cases of hyperthyroidism. ${ }^{2}$

Thyrotoxicosis affects the normal functioning of many tissues including their growth, differentiation, metabolism, and oxygen consumption. It affects the cardiovascular system profoundly. The cardiovascular manifestations of thyrotoxicosis are due to direct cellular effects of thyroid hormones on the heart and indirect cellular effects resulting from interactions with the sympathetic nervous system, alterations in peripheral vascular smooth muscle (VSM), rennin-angiotensinaldosterone system, and erythropoietin production. ${ }^{3}$

Thyroid hormone modulates cardiac function through regulation of the expression of some structural and regulatory genes. Within the myocardial cells are the fast $\alpha$-myosin heavy chain and the slow $\beta$-myosin heavy chain which mediate contraction. Thyroid hormone upregulates $\alpha$-gene which has higher ATPase activity and contractile properties and decreases the expression of $\beta$-gene with lower contractile properties. Thyroid hormone also upregulates the rate of $\mathrm{Ca}^{2+}$ release and reuptake by the sarcoplasmic reticulum and downregulates the inhibitor, phospholamban. The increase in cytosolic calcium increases systolic contraction and the more rapid calcium reuptake enhances diastolic relaxation in the heart. ${ }^{4-6}$

The sodium potassium ATPase, the voltage-gated potassium channels, and the sodium calcium exchanger are ion channels that are activated in thyrotoxicosis and they coordinate the electrochemical responses of the myocardium during cardiac contraction and relaxation. ${ }^{6-8}$ The $\beta$-adrenergic receptors are thought to be stimulated in thyrotoxicosis, leading to an increase in the intracellular second messenger, cAMP, which in turn accelerates diastolic depolarization and increases heart rate. The natriuretic peptides are secreted by cardiac myocytes ${ }^{9}$ and are said to be upregulated by thyroid hormones. The pacemaker-related genes, hyperpolarizationactivated cyclic nucleotide-gated channels 2 and 4, are also transcriptionally regulated by thyroid hormone. ${ }^{10,11}$

It has been suggested that hyperthyroidism resembles a hyperadrenergic state; however, there is no evidence that thyroid hormone excess enhances the sensitivity of the heart to adrenergic stimulation. ${ }^{11-13}$ Indeed, the role of the sympathetic nervous system in the pathophysiology of hyperthyroidism is unclear. ${ }^{12}$ The clinical spectrum of symptoms in thyrotoxicosis suggests a hyperadrenergic state strengthened by the fact that the administration of $\beta$-adrenoceptor antagonists dramatically ameliorates the clinical state. ${ }^{14-16}$ In spite of this known fact, the concentrations of catecholamines in both plasma ${ }^{17}$ and urine ${ }^{18}$ are normal or low in hyperthyroidism.

Thyrotoxicosis increases endothelial nitric oxide production via the triiodothyronine (T3)-mediated effects of thyroid receptor on the protein kinase pathway. ${ }^{19-21}$ Nitric oxide synthesized in endothelial cells then acts in a paracrine manner on adjacent VSM cells to facilitate vascular relaxation. Relaxation of VSM leads to decreased peripheral resistance and pressure, increased blood return to the heart, and increased blood volume which increases cardiac output (CO). Increased vascularity and angiogenesis reported in thyrotoxicosis may also lead to increased blood volume and $\mathrm{CO} .{ }^{22}$

The other factors that increase $\mathrm{CO}$ include activation of renin-angiotensin-aldosterone system, increased red cell mass, as well as increased blood volume: all these contribute to systemic hypertension seen in thyrotoxicosis patients. ${ }^{23}$ Hypertension contributes in causing ventricular hypertrophy and myocardial remodeling in patients with thyrotoxicosis. ${ }^{23}$ Diastolic and mean arterial blood pressures are reduced because of peripheral vasodilatation that occurs in thyrotoxicosis. ${ }^{23}$ Pulmonary arterial hypertension also occurs in hyperthyroidism and it has been attributed to pulmonary vascular endothelial dysfunction, damage due to autoimmune process, increased metabolism of intrinsic pulmonary vasodilators, and high $\mathrm{CO}$ state. ${ }^{24}$ In some cases, pulmonary hypertension may result in right heart failure. ${ }^{24}$

Another effect of thyrotoxicosis on the vasculature is its anti-atherosclerotic effects through blood vessel dilatation and production of vasodilatory molecules. In contrast, in people with hypothyroidism, atherosclerosis has been attributed to hypercholesterolemia, hypertension, and impaired endothelial function, leading to increased cardiovascular risk. Treatment of hypothyroidism with thyroid hormone replacement restores euthyroidism and reverses the associated risk ratio..$^{25}$

Echocardiography is a very useful, non-invasive, easily accessible, and perhaps an affordable tool for studying the structure and physiological function of the heart. Assessment of ventricular function, particularly the left ventricle, is one of the commonest and most important applications of echocardiography. Echocardiographic examination of left ventricular (LV) function is useful in assessment of the effect of thyrotoxicosis on the heart.

The presence of LV dysfunction is a reliable prognostic indicator in all forms of cardiac disease. Indeed, echocardiographic findings may alter the course of management and provide opportunities for appropriate therapeutic intervention.

\section{Objective}

We studied patients who had thyrotoxicosis and assessed its effect on LV function. Echocardiographic study of these patients was done with a view to stratifying them according to the pattern of LV dysfunction. 


\section{Methods}

We recruited 50 subjects with thyrotoxicosis who were aged 15 years and above and of both sexes, over a period of 1 year. The patients were recruited consecutively as they attended the medical out-patient unit of the University of Nigeria Teaching Hospital, Enugu after clinical and thyroid function assessments. Written consent was signed by the subjects and controls. The University of Nigeria Teaching Hospital Ethical committee approved the study and it was carried out in accordance with the Declaration of Helsinki ethical principles for medical research involving human subjects. ${ }^{26}$

Echocardiography was done with a Sonos 2000 HP machine (Hewlett Packard, the Netherlands, Amsterdam) to assess LV systolic and diastolic functions. Transthoracic echocardiographic examinations were performed in all participants with $3.5 \mathrm{MHz}$ transducer according to the recommendations of the American Society of Echocardiography. ${ }^{27}$ The American Society of Echocardiography recommends that measurements should be taken from trailing edge to leading edge. All the measurements were done with the picture frozen on the screen and with in-built calipers of the echocardiographic equipment. The mean measurements were taken from three consecutive cycles. The measurements were initially taken by two examiners. Thereafter, all the measurements were taken by the same echocardiographer. Electrocardiography was also done in all the participants.

Thyroid function tests were done with kits from Syntron Bioresearch Inc., Carlsbad, CA, USA. These kits had a correlation coefficient of 0.09869 when compared with a standard kit made by Abbott Laboratories (North Chicago, IL, USA). The Syntron kits have the following intra-assay coefficient of variation: serum-free T3 $-(6.8 \%)$, thyroidstimulating hormone $(\mathrm{TSH})-(4.3 \%)$, total free $\mathrm{T} 3-(4.4 \%)$, total tetraiodothyronine $-(7.2 \%){ }^{28}$

Exclusion criteria included patients with:

a) pre-existing hypertension (blood pressure $\geq 140$ /

$90 \mathrm{mmHg}$, or were on antihypertensive drugs before the onset of thyrotoxicosis);

b) diabetes mellitus (fasting blood glucose $>6.1 \mathrm{mmol} / \mathrm{L}$ );

c) coronary artery disease (detected by electrocardiography);

d) anemia (hemogram $<12 \mathrm{gm} / \mathrm{L}$ );

e) chronic alcohol consumption;

f) history of smoking, intake of illicit drugs, intake of herbal drugs, cardiotoxic drug consumption, pregnant state.

The controls were 50 age- and sex-matched subjects who do not have thyrotoxicosis and/or any co-morbidity.

\section{Definitions}

A serum-free T3 $>4.2 \mathrm{pg} / \mathrm{L}$ and a concomitant suppressed TSH of $>0.5 \mu \mathrm{U} / \mathrm{mL}$ was used to diagnose thyrotoxicosis. The following parameters were defined as follows: $:^{27-32}$

a) LV systolic dysfunction was present if there was any one of the following: i) LV ejection fraction $<50 \%$, ii) fractional shortening (FS) $<30 \%$, iii) cardiac index $<2.8 \mathrm{~L} /$ $\mathrm{min} / \mathrm{m}^{2}$, iv) $\mathrm{CO}<4 \mathrm{~L} / \mathrm{min}, \mathrm{v}$ ) mean velocity of circumferential fiber (VCF) shortening $<1.02$ circumferences $/ \mathrm{sec}$, and vi) peak aortic systolic velocity $<72 \mathrm{~cm} / \mathrm{sec}$;

b) LV diastolic dysfunction was present if there was any one of the following: LV E/A (early diastolic velocity/velocity with atrial contraction) $<1.1$, isovolumic relaxation time $>90 \mathrm{msec}$, E wave deceleration time $>210 \mathrm{msec}$, peak filling rate $<5$ );

c) enhanced (meaning increased myocardial contractility) systolic function ${ }^{33}$ was present if there was any one of the following: ejection fraction $>75 \%$, FS $>42 \%$, CO $>7 \mathrm{~L} / \mathrm{min}$, peak aortic systolic velocity $>120 \mathrm{~cm} / \mathrm{sec}$;

d) enhanced (meaning increased) diastolic function ${ }^{34}$ was present if there was documentation of any one of the following: E wave velocity $>72 \mathrm{~cm} / \mathrm{sec}$, A wave velocity $>59 \mathrm{~cm} / \mathrm{sec}$, isovolumic relaxation time $<76 \mathrm{msec}$, E wave deceleration time $<179$ msec in the thyrotoxicosis patients and age- and sex-matched control subjects;

e) left ventricular mass index (LVMI ${ }^{27}$ normal value: 43-96 g/ $\mathrm{m}^{2}$ (for women) and 49-116 $\mathrm{g} / \mathrm{m}^{2}$ (for men);

f) relative wall thickness ${ }^{27}$ of $>0.43$ indicates concentric hypertrophy; and $<0.43$ indicates eccentric hypertrophy.

\section{Statistics}

Continuous variables were expressed as mean \pm 1 standard error of mean. Statistical comparisons were performed using SPSS software (version 15.0; SPSS Inc., Chicago, IL, USA). $P<0.05$ was considered significant.

\section{Results}

Thyrotoxicosis patients were leaner, and when their blood pressure was compared with controls there was no significant difference (Table 1). Palpitation was the commonest symptom, enlarged thyroid gland was present in more than $50 \%$ of the patients, and Graves' disease was documented in $40 \%$ of the subjects (Table 2)

Echocardiographic measurements showed that the mean intra-observer agreement was $97 \%(\mathrm{k}=0.86)$ and the mean inter-observer agreement was $92 \%(\mathrm{k}=0.78)$. This indicated that intra-observer and inter-observer variability were negligible. Out of all 50 patients studied, eight (16\%) had 
Table I Anthropometric data and blood pressure of patients and controls

\begin{tabular}{|c|c|c|c|c|}
\hline Parameters & $\begin{array}{l}\text { Thyrotoxicosis patients: } \\
\text { mean (SD) }\end{array}$ & Control: mean (SD) & $\begin{array}{l}\text { Student's } \\
\text { t-test value }\end{array}$ & $P$-value \\
\hline Age & $44(3.1)$ & $43.5(5.2)$ & 0.85 & $>0.05$ \\
\hline Weight (kg) & $56.0(5.5)$ & $65(7.6)$ & -6.4 & $<0.05^{*}$ \\
\hline Height (meters) & $159.5(6.8)$ & $160.8(15.9)$ & 1.35 & $>0.05$ \\
\hline Body surface area $\left(\mathrm{m}^{2}\right)$ & $1.2(2.4)$ & $1.6(0.17)$ & 1.85 & $<0.5^{*}$ \\
\hline Body mass index $\left(\mathrm{kg} / \mathrm{m}^{2}\right)$ & $22.04(6.4)$ & $25.09(5.4)$ & -1.87 & $<0.05^{*}$ \\
\hline Pulse (beats/min) & $102(11.9)$ & $78(5.2)$ & 8.57 & $<0.01 *$ \\
\hline Systolic blood pressure (mmHg) & $124.2(12.5)$ & $122.9(2.8)$ & 0.12 & $>0.05$ \\
\hline Diastolic blood pressure $(\mathrm{mmHg})$ & $75(I I .4)$ & $79.1(6.5)$ & 1.5 & $>0.05$ \\
\hline
\end{tabular}

Note: *Represents significant value.

Abbreviation: SD, standard deviation.

heart failure. Five of these patients had systolic heart failure with reduced ejection fraction: a typical echocardiogram is depicted in Figure 1. The other three patients had heart failure with preserved ejection fraction. No patient had the so-called high-output heart failure, ie, heart failure with increased ejection fraction.

The left ventricle was dilated in $28 \%$ of the patients. The LV end diastolic diameter was significantly higher in the thyrotoxicosis patients than in the controls $(5.35 \mathrm{~cm} 0.76$ standard deviation [SD] versus [vs] $5.0 \mathrm{~cm} 0.73 \mathrm{SD}-P<0.05$ ) (Table 3). When all the thyrotoxicosis subjects were compared with control, it showed that the index patients with thyrotoxicosis had significantly increased systolic function $(P<0.01)$, supporting the hyperdynamic clinical state of the disease (Table 3). Enhanced systolic function depicted in Figure 2 was documented in 14 patients, and their systolic parameters showed significant difference when compared with that of the control $-P<0.01$ (Table 4).

Enhanced diastolic function depicted in Figure 3 was documented in 17 thyrotoxicosis patients and when parameters of diastolic function were compared with control, there was significant difference $-P<0.01$ (Table 5) . It is obvious that some patients had combined enhanced systolic and enhanced diastolic functions.

Diastolic dysfunction (Figure 4) was seen among 17 patients. Table 6 shows that there was significant

Table 2 Frequencies of symptoms in thyrotoxicosis patients

\begin{tabular}{ll}
\hline Symptoms & Patients (percentage) \\
\hline Palpitation & $30(60)$ \\
Enlarged thyroid gland & $26(52)$ \\
Weight loss & $24(48)$ \\
Heat intolerance & $23(46)$ \\
Tremulousness & $21(42)$ \\
Proptosis (Graves' patients) & $20(40)$ \\
Increased sweating & $18(38)$ \\
Polyphagia & $16(32)$ \\
\hline
\end{tabular}

difference between thyrotoxicosis patients and controls when parameters of diastolic function were assessed $-(P<0.01)$.

The inter-ventricular septal thickness and the posterior ventricular wall thickness were significantly higher in the thyrotoxicosis group than in the control: $(0.95 \mathrm{~cm}$ vs $0.77 \mathrm{~cm}-$ $P<0.05$.) and $(0.89 \mathrm{~cm}$ vs $0.79 \mathrm{~cm}-P<0.05)$, respectively. Four percent of the patients had inter-ventricular septal thickness $>12 \mathrm{~mm}$. The LVMI of subjects $\left(127.03 \mathrm{~g} / \mathrm{m}^{2}\right)$ was also significantly higher than in the control $\left(84.14 \mathrm{~g} / \mathrm{m}^{2}\right)$ at $P<0.05$, and the relative wall thickness was significantly higher in thyrotoxicosis patients than in the control ( 0.53 vs $0.33-P<0.05$ ). In effect, the thyrotoxicosis patients had eccentric hypertrophy. Figure 5 shows that 17 (34\%) thyrotoxic patients had LV hypertrophy using LVMI. Thirtythree $(66 \%)$ thyrotoxic patients had normal LVMI. Only one (2\%) subject in the control had increased LVMI.

Figure 6 summarizes the echocardiographic findings in the 50 thyrotoxicosis patients studied. Table 7 shows the multivariate regression analysis between all the systolic and diastolic parameters and TSH and T3 of the patients with thyrotoxicosis and control. Both T3 and TSH models showed a good fit $\left(R^{2}=0.42, P<0.1\right.$, and $P<0.05$, respectively). T3 retained its independent positive association with the systolic and diastolic parameters. TSH also retained its independent negative association with the systolic and diastolic parameters.

\section{Discussion}

Our study documented enhanced systolic and diastolic functions when the subjects were compared with controls (Tables 4 and 5), and these findings are in keeping with other reports which documented that patients who have thyrotoxicosis also have increased LV systolic and diastolic contractile functions, resulting from upregulation of contractile and calcium-regulatory proteins. ${ }^{35-37}$ 


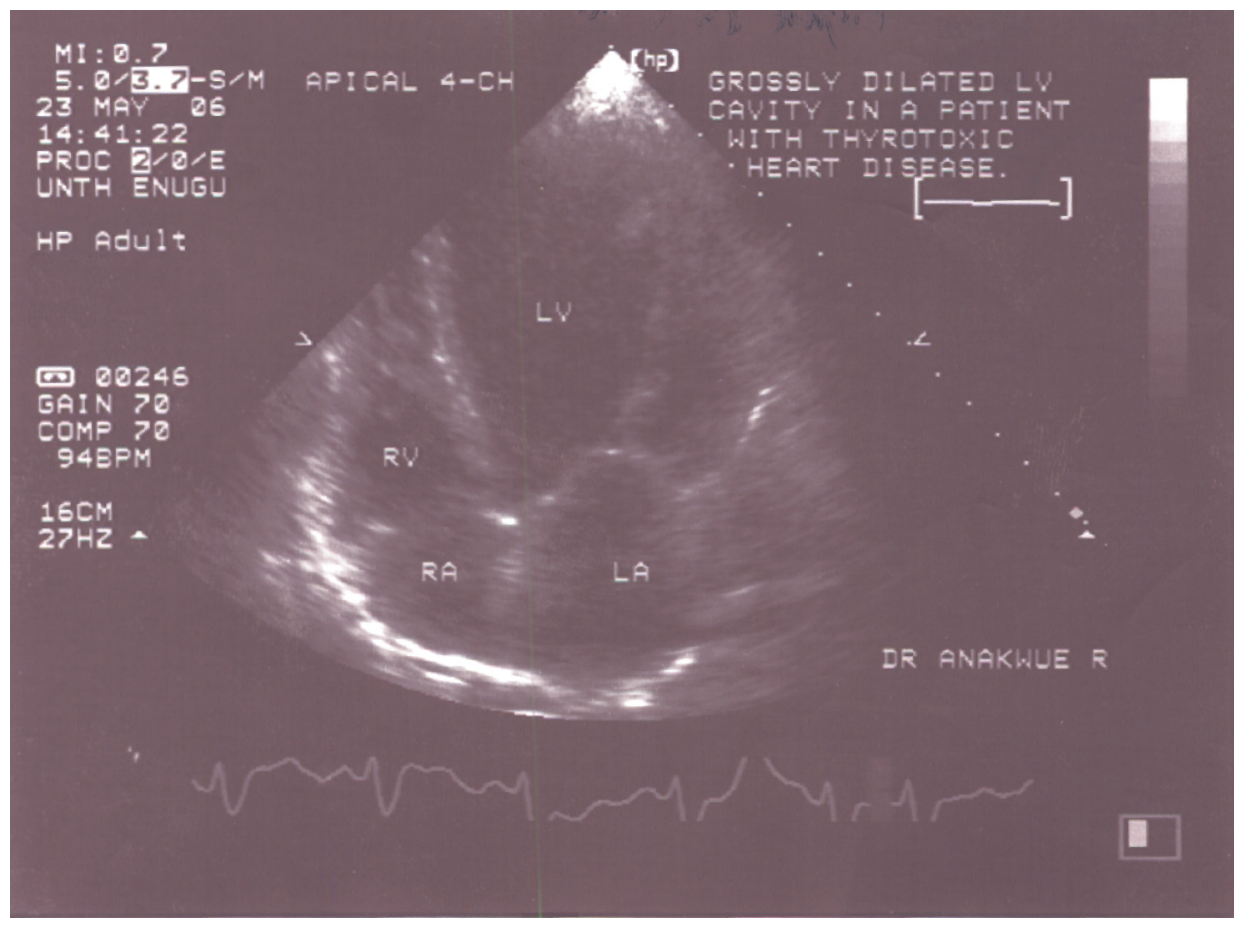

Figure I Two-dimensional echocardiogram showing dilated heart chambers - systolic dysfunction.

Friedman et $\mathrm{al}^{138}$ in the USA had reported enhanced systolic function by documenting the echocardiographic tracing of the septum and left posterior wall. Kral et al ${ }^{39}$ in Czecholoslavakia studied 12 patients with hyperthyroidism and documented significant increase in mean VCF as well as cardiac index, stroke volume, and LV end diastolic volume. In Poland, Marcisz et al while studying hyperthyroidism, noted that it was associated with enhanced systolic function. ${ }^{40}$ They demonstrated increased LV ejection function, FS, mean VCF, cardiac index and output-pressure index. So our study, which showed an increase of $18 \%$ and $19 \%$ in the LV ejection fraction and FS, respectively, in thyrotoxicosis patients when compared with control is not a new finding. Enhanced systolic function has also been documented in an animal

Table 3 Comparison of parameters of left ventricular systolic function between thyrotoxicosis patients and control

\begin{tabular}{|c|c|c|c|c|}
\hline Parameters & $\begin{array}{l}\text { Mean values for thyrotoxicosis } \\
\text { patients (SD) [reference range] }\end{array}$ & $\begin{array}{l}\text { Mean values for } \\
\text { control (SD) }\end{array}$ & $\begin{array}{l}\text { Student's } \\
\text { t-test value }\end{array}$ & P-value \\
\hline \multirow[t]{2}{*}{ LVEF (\%) } & $69.7(10.2)$ & $59(3.3)$ & 2.47 & $<0.0 I^{*}$ \\
\hline & {$[4 \mid-79]$} & & & \\
\hline \multirow[t]{2}{*}{ FS (\%) } & $43.9(9.8)$ & $36.83(8.4)$ & 2.8 & $<0.01 *$ \\
\hline & {$[12-48]$} & & & \\
\hline \multirow[t]{2}{*}{ Cardiac output (L) } & $7.15(1.47)$ & $4.7(0.67)$ & 7.64 & $<0.0 I^{*}$ \\
\hline & {$[3.5-8.0]$} & & & \\
\hline \multirow[t]{2}{*}{ Cardiac index L/min $/ \mathrm{m}^{2}$} & $4.1(0.84)$ & $3.2(0.29)$ & 4.13 & $<0.0 I^{*}$ \\
\hline & {$[2.1-4.8]$} & & & \\
\hline \multirow[t]{2}{*}{ Peak aortic systolic velocity (cm/seconds) } & $144(26.7)$ & $113(11.5)$ & 7.5 & $<0.0 I^{*}$ \\
\hline & {$[8 \mid-165]$} & & & \\
\hline \multirow[t]{2}{*}{ VCF (circumferences/second) } & $1.74(0.34)$ & $1.21(0.12)$ & 11.0 & $<0.0 I^{*}$ \\
\hline & {$[1.8-2.1]$} & & & \\
\hline End diastolic diameter & $5.35 \mathrm{~cm}(0.76)$ & $5.0 \mathrm{~cm}(0.73)$ & & $<0.01 *$ \\
\hline Interventricular septal thickness & $0.95 \mathrm{~cm}(0.12)$ & $0.77 \mathrm{~cm}(0.7)$ & & $0.05^{*}$ \\
\hline Posterior wall thickness & $0.89 \mathrm{~cm}(0.4)$ & $0.79 \mathrm{~cm}(0.9)$ & & $0.05^{*}$ \\
\hline Left ventricular mass index & $127(32.3)$ & $84(13.8)$ & & $0.05^{*}$ \\
\hline Relative wall thickness & $0.53(0.15)$ & $0.33(1.4)$ & & $0.05^{*}$ \\
\hline
\end{tabular}

Note: *Represents significant value.

Abbreviations: LVEF, left ventricular ejection fraction; SD, standard deviation; FS, fractional shortening; VCF, velocity of circumferential fiber. 


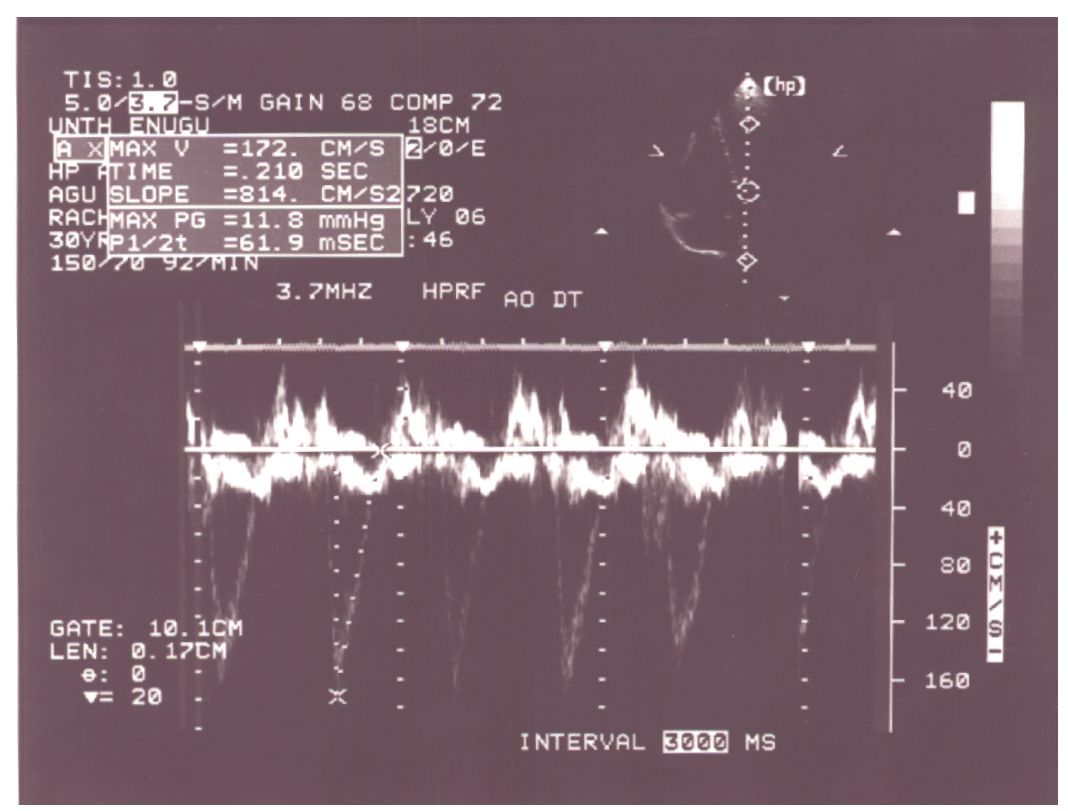

Figure 2 Apical four chamber view with continuous wave Doppler showing increased aortic flow velocity in a patient with enhanced systolic function in thyrotoxicosis.

study involving 103 cats with hyperthyroidism in which Bond et $\mathrm{al}^{41}$ showed enhancement of indices of contractility: $21.4 \%$ in $\mathrm{FS}$ and $14.6 \%$ in mean VCF.

Mintz et $\mathrm{al}^{37}$ had documented the presence of enhanced diastolic function in nine newly diagnosed and untreated hyperthyroid patients, which normalized following attainment of euthyroid state. They concluded that their findings of enhanced cardiac diastolic performance did not support the hypothesis that thyrotoxicosis was associated with compromised LV function and suggested the possibility that the cardiac symptoms that accompany hyperthyroidism may be due to non-cardiac mechanisms. ${ }^{37}$ This conclusion can be said to be valid only for patients with enhanced function, because enhanced diastolic function is an early state of thyrocardiac disease and is unlikely to be associated with any cardiac abnormality. Enhanced diastolic function results from enhanced myocardial relaxation, which is due to increased calcium reuptake by the sarcoplasmic reticulum. ${ }^{37}$

The management of enhanced systolic and diastolic functions is achieved by rendering the patient euthyroid through the use of anti-thyroid therapy. The judicious use of anti-thyroid drugs in addition to $\beta$-adrenoceptor blockade will lead to decreased calcium release and reuptake from the sarcoplasmic reticulum, which reverses the enhanced systolic and diastolic functions, respectively. $\beta$ blockade with propranolol decreases end systolic volume, whereas anti-thyroid therapy with carbimazole reduces end diastolic volume. ${ }^{42}$ In other words, while $\beta$-adrenoceptor blockade depresses myocardial contractility, anti-thyroid therapy reverses the primary hemodynamic disturbance responsible for the increase in stroke volume. ${ }^{42}$

Table 4 Comparison of proportions of left ventricular enhanced systolic function parameters between thyrotoxicosis patients and control

\begin{tabular}{|c|c|c|c|c|}
\hline Parameters & $\begin{array}{l}\text { Proportions found in } \\
\text { thyrotoxicosis patients }\end{array}$ & $\begin{array}{l}\text { Proportions found } \\
\text { in control }\end{array}$ & $\begin{array}{l}\text { Student's } \\
\text { t-test value }\end{array}$ & $P$-value \\
\hline LVEF $>75 \%$ & 0.22 & 0.04 & 5.9 & $<0.01 *$ \\
\hline $\mathrm{FS}>45 \%$ & 0.28 & 0.06 & 5.15 & $<0.01 *$ \\
\hline Cardiac index $>4.2 \mathrm{~L} / \mathrm{min} / \mathrm{m}^{2}$ & 0.30 & 0.0 & 4.32 & $<0.01 *$ \\
\hline Cardiac output $>7 \mathrm{~L}$ & 0.28 & 0.0 & 4.32 & $<0.01 *$ \\
\hline $\begin{array}{l}\text { Peak aortic systolic velocity }(\mathrm{cm} / \mathrm{s})>120 \mathrm{~cm} / \\
\text { seconds }\end{array}$ & 0.22 & 0.06 & 2.18 & $<0.05^{*}$ \\
\hline VCF (circumferences/second) $>1.9$ & 0.26 & 0.06 & 2.34 & $<0.05^{*}$ \\
\hline
\end{tabular}

Note: *Represents significant value.

Abbreviations: LVEF, left ventricular ejection fraction; FS, fractional shortening; VCF, velocity of circumferential fiber; $P_{T}$, proportions found in thyrotoxicosis patients; $P_{C}$, proportions found in controls. 


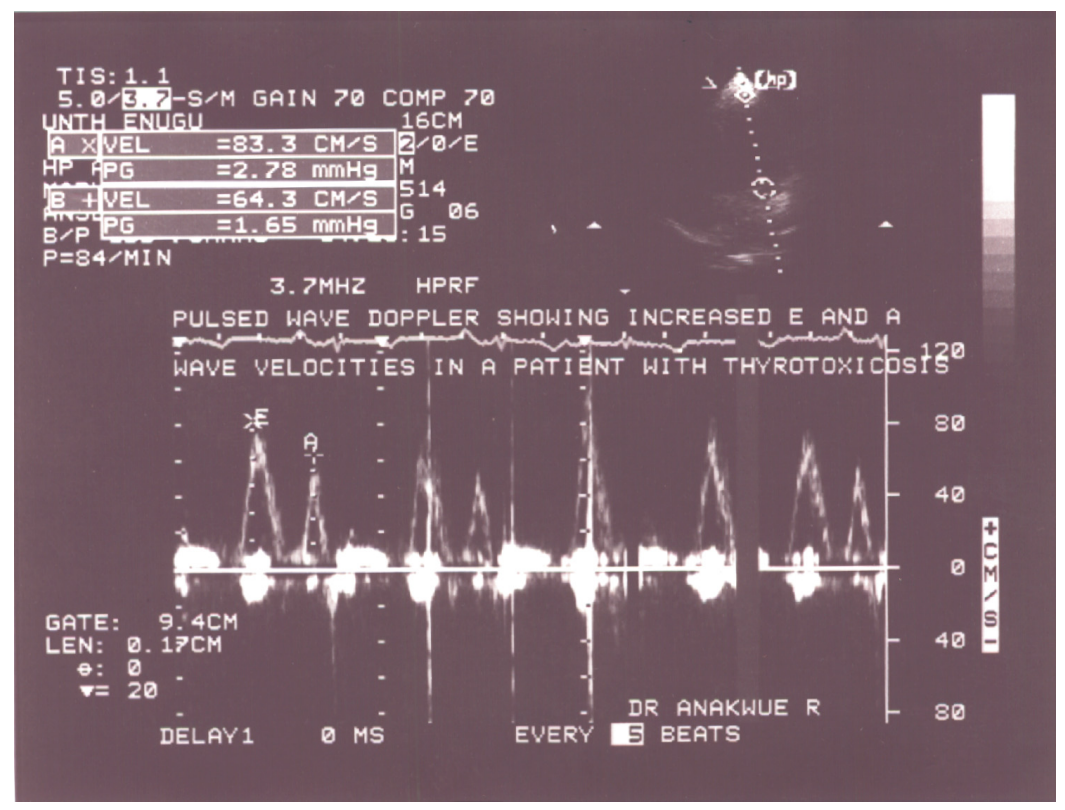

Figure 3 Apical four chamber view with pulse wave Doppler showing increased mitral E and A wave velocities in keeping with enhanced diastolic function.

$\beta$-adrenoceptor blockade has been used to modify the severity of hyperadrenergic symptoms of thyrotoxicosis and to treat tachycardia. Many $\beta$-adrenoceptors have been used, but propranolol and the longer-acting atenolol are more popular. ${ }^{43}$ Propranolol has two roles in the treatment of hyperthyroidism, determined by the different isomers of propranolol. L-propranolol causes $\beta$-blockade, thus treating the symptoms associated with hyperthyroidism such as tremor, palpitations, anxiety, and heat intolerance. ${ }^{43} \mathrm{D}$-propranolol inhibits thyroxine deiodinase, thereby blocking the conversion of tetraiodothyronine to $\mathrm{T} 3$, providing some though minimal therapeutic effect. ${ }^{44}$ Atenolol is a selective beta blocker and so less likely than propranolol to cause bronchoconstriction in patients who have bronchial disease. ${ }^{44}$

Impaired diastolic dysfunction was found in at least $28 \%$ of the thyrotoxicosis patients in our study (Figure 4). These patients with diastolic dysfunction had no symptoms arising from the cardiovascular system. But it has been documented that the finding of diastolic dysfunction in an asymptomatic patient is a risk factor for the future development of heart failure, and the early identification of such patients provides a window of opportunity to prevent progression of what appears to be a preclinical heart disease. ${ }^{45-47}$

In a study in India, which involved 43 patients with newly diagnosed hyperthyroidism and 45 healthy participants, Jing et $\mathrm{al}^{48}$ reported that the patients had impaired LV diastolic function. Diastolic dysfunction can also occur in sub-clinical hyperthyroidism. Smit et al in the Netherlands showed in a randomized placebo-controlled study that reversible diastolic dysfunction can occur after long-term exogenous subclinical hyperthyroidism. ${ }^{49}$ They were concerned that even isolated diastolic dysfunction may be associated with increased mortality. ${ }^{49}$ Yue et al in the People's Republic of China also documented that LV diastolic dysfunction can occur in patients who present with heart failure. ${ }^{50}$ In that study, out of the $6 \%$ of patients who had heart failure, half of them had heart failure with preserved ejection fraction. They concluded that diastolic dysfunction may play an important

Table 5 Comparison of proportions of left ventricular enhanced diastolic function parameters of thyrotoxicosis patients and control

\begin{tabular}{|c|c|c|c|c|}
\hline Parameters & $\begin{array}{l}\text { Proportions of thyrotoxicosis } \\
\text { patients }\end{array}$ & $\begin{array}{l}\text { Proportions of } \\
\text { control }\end{array}$ & $\begin{array}{l}\text { Student's } \\
\text { t-test value }\end{array}$ & P-value \\
\hline Peak early filling velocity $(E)>72 \mathrm{~cm} / \mathrm{s}$ & 0.34 & 0.02 & 12.77 & $<0.0 I^{*}$ \\
\hline Peak velocity at atrial contraction $(A)>59 \mathrm{~cm} / \mathrm{s}$ & 0.20 & 0.00 & 4.32 & $<0.01 *$ \\
\hline IVRT $<76 \mathrm{~m} / \mathrm{sec}$ & 0.30 & 0.04 & 8.41 & $<0.01 *$ \\
\hline EDT $<179 \mathrm{~m} / \mathrm{sec}$ & 0.30 & 0.00 & 4.32 & $<0.01 *$ \\
\hline
\end{tabular}

Note: *Represents significant value.

Abbreviations: IVRT, isovolumic relaxation time; EDT, E wave deceleration time; E, early diastolic velocity; A, velocity with atrial contraction. 

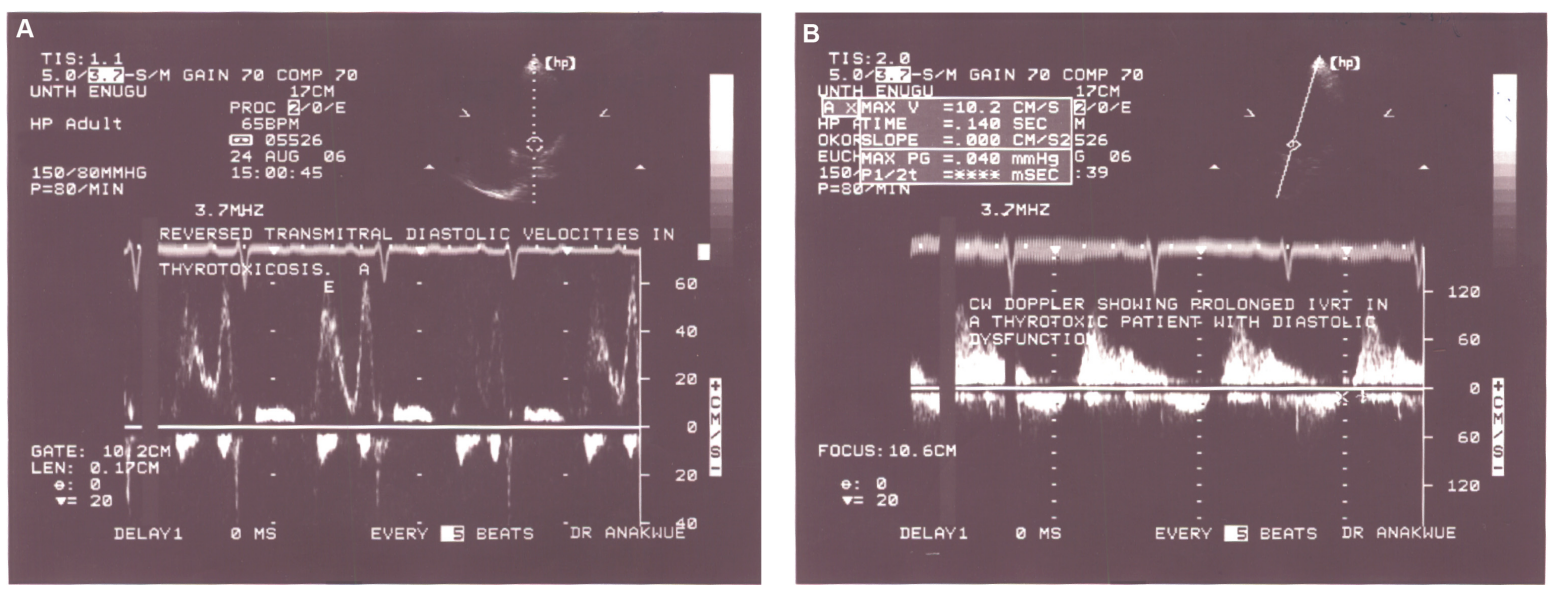

Figure 4 Pulse wave Doppler images demonstrating diastolic dysfunction.

Notes: (A) Pulse wave Doppler showing reversed transmitral diastolic velocities in thyrotoxicosis. (B) Pulse wave Doppler of transmitral flow showing prolonged isovolumic relaxation time.

role in the pathogenesis of heart failure in thyrotoxicosis. ${ }^{50}$ We also documented diastolic dysfunction as being a cause of heart failure with preserved ejection fraction in this study (Figure 6).

In effect, thyrotoxic heart failure may present with preserved, reduced, or increased ejection fraction (high-output heart failure). ${ }^{32,51}$ In our earlier study, we reported that $10 \%$ of the patients with thyrotoxicosis had systolic dysfunction with preserved ejection fraction. ${ }^{52}$ Similar findings have been found in other studies. ${ }^{53,54}$ This is an indication that echocardiography can be used to classify cardiac dysfunction in patients with thyrotoxicosis, including the determination of the ejection fraction, and these data are indispensable in planning a therapeutic regimen.

Patients who have diastolic dysfunction can only be detected using echocardiography, and this invariably influences their management. Therapeutic management of patients with diastolic dysfunction may differ from those with systolic dysfunction. Patients with isolated diastolic dysfunction will respond to anti-thyroid drugs (to render them euthyroid), $\beta$-blockers, and diuretics in moderate doses..$^{50}$ Inotropes which are useful in patients with systolic dysfunction will not be required in patients with isolated diastolic dysfunction..$^{50}$

In thyrotoxicosis patients who have heart failure with preserved or increased ejection fraction, inotropes are of doubtful therapeutic effect. ${ }^{51}$ Anti-hyperthyroid drugs, judicious use of diuretics, and some $\beta$-adrenoceptor blockers are more useful in managing this group of patients. ${ }^{55}$ The use of vasodilators like angiotensin-converting inhibitors, angiotensin receptor blockers, and $\beta$-blockers with vasodilatory properties (eg, carvedilol, nebivolol) may aggravate the clinical condition in heart failure with increased ejection fraction because of associated decreased peripheral vascular resistance. $^{51}$

Heart failure with reduced ejection fraction may be found in patients with thyrotoxicosis in spite of the fact that it is a hypermetabolic condition. Some predisposing conditions include pre-existing hypertension, ischemic heart disease, and mitral valve disease, which may be found in Graves' and Hashimoto's diseases. ${ }^{56,57}$ The pathophysiology of thyrotoxic cardiac disease with reduced ejection fraction may include direct damage due to autoimmune myocarditis, congestive circulation secondary to excess sodium, and fluid retention

Table 6 Comparison of proportions of left ventricular diastolic dysfunction parameters of thyrotoxicosis patients and control

\begin{tabular}{|c|c|c|c|c|}
\hline Parameters & $\begin{array}{l}\text { Proportions of thyrotoxicosis } \\
\text { patients }\end{array}$ & $\begin{array}{l}\text { Proportions of } \\
\text { control }\end{array}$ & $\begin{array}{l}\text { Student's } \\
\text { t-test value }\end{array}$ & $P$-value \\
\hline E/A ratio $<\mathrm{I} . \mathrm{I}$ & 0.34 & 0.02 & 14.65 & $<0.01 *$ \\
\hline IVRT $>90 \mathrm{msec}$ & 0.28 & 0.00 & 4.10 & $<0.01 *$ \\
\hline EDT $>210 \mathrm{msec}$ & 0.28 & 0.06 & 5.98 & $<0.01 *$ \\
\hline PFR $<5$ & 0.34 & 0.00 & 4.90 & $<0.01 *$ \\
\hline
\end{tabular}

Note: *Represents significant value.

Abbreviations: E, early diastolic velocity; A, velocity with atrial contraction; E/A ratio, ratio of early mitral flow velocity to velocity during atrial contraction; IVRT, isovolumic relaxation time; EDT, E wave deceleration time; PFR, peak filling rate. 


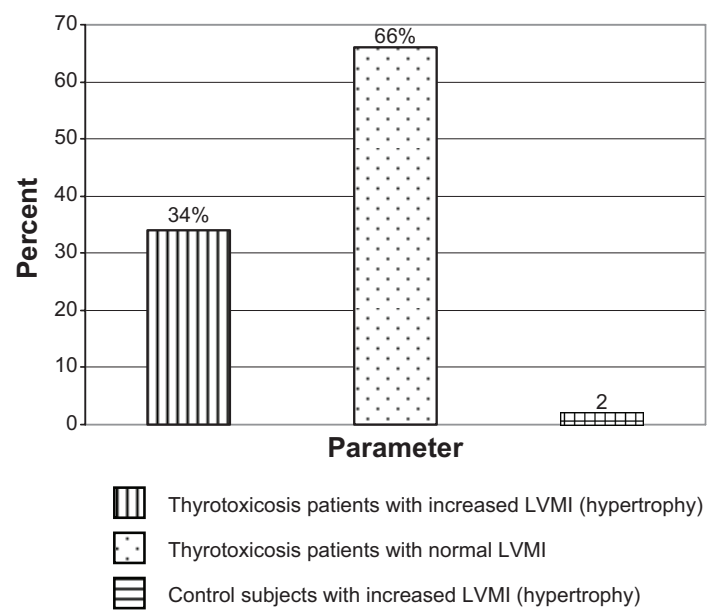

Figure 5 Bar chart showing the percentage of thyrotoxicosis patients with left ventricular hypertrophy using left ventricular mass index (LVMI).

related to hyperthyroidism, upregulation of the reninangiotensin-aldosterone system, sustained tachycardia, and/ or atrial fibrillation. ${ }^{41}$ Some of the arrhythmias, particularly atrial fibrillation, predisposes to increased mortality in thyrotoxicosis patients and worsens prognosis when associated with heart failure. ${ }^{58,59}$ It should be emphasized that atrial fibrillation is associated with increased mortality in thyrotoxicosis and so it should be treated appropriately whenever it occurs. ${ }^{60} \beta$-adrenoceptor blockade, digoxin, calcium channel blockers, and anticoagulants are all useful in the management of atrial fibrillation associated with thyrotoxicosis.

Patients with systolic dysfunction with reduced ejection fraction and tachycardia will benefit from treatments aimed at slowing the heart rate or controlling the ventricular response in atrial fibrillation. This appears to improve LV function even before initiation of anti-thyroid therapy. ${ }^{57}$ This class

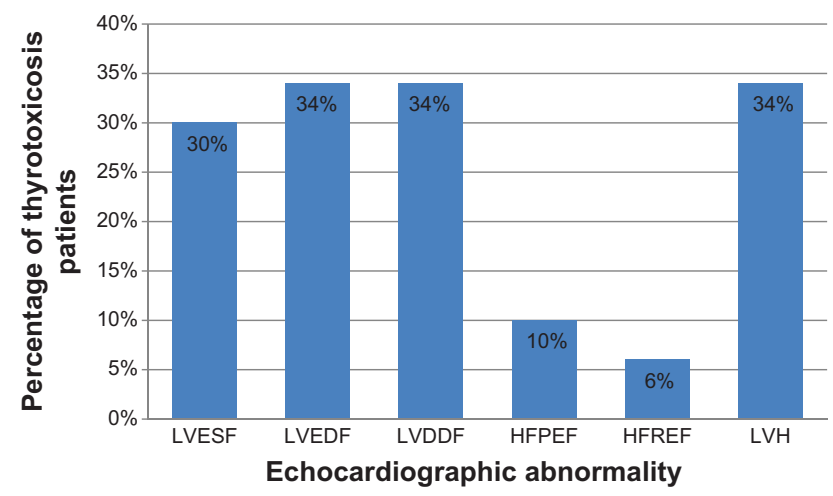

Figure 6 The echocardiographic abnormalities seen in the study.

Abbreviations: LVESF, left ventricular enhanced systolic function; LVEDF, left ventricular enhanced diastolic function; LVDDF, left ventricular diastolic dysfunction; HFPEF, heart failure with preserved ejection fraction; HFREF, heart failure with reduced ejection fraction; LVH, left ventricular hypertrophy. of patients with dilated, poorly contracting hearts will also benefit from inotropes, in conjunction with classic forms of treatment for congestive heart failure. However, larger than usual doses of inotropes such as digoxin may be required. A relative resistance to digoxin may be present, due both to increased renal clearance, ${ }^{61}$ increased biliary excretion, ${ }^{62}$ and the increased number of $\mathrm{Na} / \mathrm{K}$ ATPase units in the cardiac muscle. ${ }^{63}$

There may be no clinical trials in support of the use of $\beta$-adrenoceptor blockers in thyrotoxic heart failure, but they are effective in alleviating the attendant symptoms of hyperthyroidism and also in reducing heart rate. However, invasive monitoring in hyperthyroid patients with cardiac failure $^{64}$ has demonstrated depressed myocardial function in response to $\beta$-adrenoceptor blockade, demonstrated by decreased stroke volume and increased pulmonary artery diastolic pressure.

If thyrotoxic heart failure is truly congestive with associated fluid retention, $\beta$-adrenoceptor blockers, which are really negatively inotropic, should be stepped down until the patient is hemodynamically stable. This is in spite of the fact that $\beta$-adrenoceptor blockers are indicated in the current guidelines for management of heart failure. A practical guideline for the use of $\beta$-adrenoceptor blockers in heart failure in thyrotoxicosis may be to optimize the reduction of fluid retention before the introduction of $\beta$ blockers that have been found to be useful in previous clinical trials on heart failure therapeutics, namely carvedilol (COPERNICUS), ${ }^{65}$ metoprolol (MERIT-HF), ${ }^{66}$ and bisoprolol (CIBIS II) ${ }^{67}$ The ultra-short acting $\beta$-adrenoceptor blockers esmolol, propranolol, and atenolol have been used in cases of heart failure associated with thyrotoxicosis as a therapeutic trial, but this practice is not widely accepted because there may be worsening of heart function. ${ }^{68-71}$

Eccentric hypertrophy was documented in this work, but concentric hypertrophy has also been seen in some thyrotoxicosis patients. ${ }^{72} \mathrm{LV}$ hypertrophy has also been documented in patients receiving thyroxine in the absence of significant changes in heart rate and blood pressure, suggesting that there is a direct trophic effect of thyroid hormone on the myocardium. ${ }^{72,73}$ There have been reports from Asia and Germany, documenting the presence of LV hypertrophy in thyrotoxicosis patients. ${ }^{74,75} \mathrm{LV}$ hypertrophy has been associated with cardiovascular events and should therefore be treated. Thyrotoxicosis patients who have LV hypertrophy should receive anti-thyroid drugs as well as beta-blockers and calcium blockers, which are known to reverse ventricular remodeling. ${ }^{76}$ 
Table 7 Correlation of thyroid-stimulating hormone and free T3 with echocardiographic parameters

\begin{tabular}{|c|c|c|c|c|}
\hline Parameters & $\begin{array}{l}\text { Pearson's correlation coefficient for } \\
\text { thyroid-stimulating hormone (TSH) }\end{array}$ & $P$-value (TSH) & $\begin{array}{l}\text { Pearson's correlation } \\
\text { coefficient for free T3 }\end{array}$ & $P$-value (FT3) \\
\hline LVEF & -0.402 & $<0.01 *$ & 0.365 & $<0.01 *$ \\
\hline FS & -0.396 & $<0.01 *$ & 0.347 & $<0.01 *$ \\
\hline $\mathrm{CO}$ & -0.283 & $<0.05^{*}$ & 0.319 & $<0.05^{*}$ \\
\hline $\mathrm{Cl}$ & -0.259 & $<0.05^{*}$ & 0.301 & $<0.05^{*}$ \\
\hline AOVMAX & -0.406 & $<0.01 *$ & 0.390 & $<0.05^{*}$ \\
\hline MVCF & -0.517 & $<0.01 *$ & 0.370 & $<0.01 *$ \\
\hline LVE & -0.368 & $<0.01 *$ & 0.301 & $<0.01 *$ \\
\hline LVA & -0.309 & $<0.01 *$ & 0.307 & $<0.01 *$ \\
\hline LVE/A & -0.013 & $>0.05$ & 0.133 & $>0.05$ \\
\hline LVIVRT & -0.033 & $>0.05$ & 0.129 & $>0.05$ \\
\hline LVDT & -0.064 & $>0.05$ & 0.206 & $>0.05$ \\
\hline PFR & -0.068 & $>0.05$ & 0.267 & $>0.05$ \\
\hline RVE & -0.402 & $<0.01$ & 0.417 & $<0.01$ \\
\hline RVA & -0.396 & $<0.01$ & 0.365 & $<0.01$ \\
\hline RVE/A & -0.145 & $>0.05$ & -0.145 & $>0.05$ \\
\hline RVDT & -0.158 & $>0.05$ & -0.106 & $>0.05$ \\
\hline
\end{tabular}

Note: $* P$-value $<0.05$ is significant.

Abbreviations: $\mathrm{Cl}$, cardiac index; AOVMAX, peak aortic maximal velocity; MVCF, mean velocity of circumferential fibre shortening; LVE, left ventricular E wave velocity; LVA, left ventricular A wave velocity; LVE/A, left ventricular E wave velocity/A wave velocity ratio; LVDT, left ventricular E wave deceleration time; PFR, peak filling rate; RVE, right ventricular E wave velocity; RVA, right ventricular A wave velocity; RVE/A, right ventricular E wave velocity/right ventricular A wave velocity ratio; RVDT, right ventricular E wave deceleration time; T3, triodothyronine; FT3, free triodothyronine; LVIVRT, left ventricular isovolumic relaxation time; LVEF, left ventricular ejection fraction.

In summary, thyrotoxicosis is a treatable cause of heart failure and so diagnosis is important and rewarding. ${ }^{.7}$ Heart failure in people with thyrotoxicosis who have increased or preserved ejection fraction, almost always resolves after euthyroid state is established, but when there is associated reduced ejection fraction, complete resolution of the heart failure may be less predictable. ${ }^{33,78}$ Table 8 summarizes the definitive treatment of thyrotoxic cardiac disease as well as the management of the associated hemodynamic changes and complications.

\section{Conclusion}

Echocardiography is useful in the stratification of cardiac function abnormalities and is indispensable in the management

Table 8 Summary of drug treatment of thyrotoxic cardiac disease and management of associated hemodynamic changes and complications

\begin{tabular}{|c|c|c|c|c|c|c|c|c|}
\hline $\begin{array}{l}\text { Clinical } \\
\text { condition }\end{array}$ & $\begin{array}{l}\text { Excessive } \\
\text { thyroid } \\
\text { hormone }\end{array}$ & Tachycardia & $\begin{array}{l}\text { Atrial } \\
\text { fibrillation }\end{array}$ & Hypertension & $\begin{array}{l}\text { Left } \\
\text { ventricular } \\
\text { hypertrophy }\end{array}$ & HF $F_{p}$ EF & HF EF & HF $E F$ \\
\hline $\begin{array}{l}\text { Drug } \\
\text { treatment }\end{array}$ & $\begin{array}{l}\text { Anti-thyroid } \\
\text { drugs eg } \\
\text { carbimazole and } \\
\text { propylthiouracil }\end{array}$ & $\begin{array}{l}\text { - Beta blockers- } \\
\text { propranolol, } \\
\text { atenolol and } \\
\text { esmolol } \\
\text { - CCB- } \\
\text { diltiazem }\end{array}$ & $\begin{array}{l}\text { - Beta blockers- } \\
\text { propranolol, } \\
\text { atenolol and } \\
\text { esmolol } \\
\text { - CCB } \\
\text { - Digoxin } \\
\text { - Amiodarone } \\
\text { - Anticoagulants }\end{array}$ & $\begin{array}{l}\text { - Beta blockers- } \\
\text { propranolol } \\
\text { and atenolol } \\
\text { - } \text { CCB }\end{array}$ & $\begin{array}{l}\text { - Beta } \\
\text { blockers } \\
\text { - } \mathrm{CCB}\end{array}$ & $\begin{array}{l}\text { - Beta blockers- } \\
\text { propranolol } \\
\text { and atenolol } \\
\text { - CCB } \\
\text { - Diuretics }\end{array}$ & $\begin{array}{l}\text { - Diuretics } \\
\text { - Digoxin } \\
\text { - Beta } \\
\text { blockers- } \\
\text { metoprolol, } \\
\text { carvedilol } \\
\text { and } \\
\text { busoprolol }\end{array}$ & $\begin{array}{l}\text { - Beta blockers } \\
\text { - } \mathrm{CCB}\end{array}$ \\
\hline Comments & $\begin{array}{l}\text { Required in } \\
\text { all cases of } \\
\text { thyrotoxicosis. } \\
\text { Pharmacokinetics } \\
\text { and pharmaco- } \\
\text { dynamics of drugs } \\
\text { are altered in } \\
\text { thyrotoxiocosis. }\end{array}$ & $\begin{array}{l}\text { Propranolol } \\
20-40 \mathrm{mg} \text { qds, } \\
\text { od/iv; Diltiazem } \\
60-120 \mathrm{mg} \text { qds, } \\
\text { od }\end{array}$ & $\begin{array}{l}\text { Esmolol is short } \\
\text { acting. Amiodarone } \\
\text { for refractory atrial } \\
\text { fibrillation. }\end{array}$ & $\begin{array}{l}\text { Propranolol also } \\
\text { inhibits T4 to T3 } \\
\text { conversion. }\end{array}$ & $\begin{array}{l}\text { These drugs } \\
\text { reverse } \\
\text { ventricular } \\
\text { re-modelling. }\end{array}$ & $\begin{array}{l}\text { Atenolol is } \\
\text { less likely than } \\
\text { propranolol to } \\
\text { cause broncho- } \\
\text { constriction. }\end{array}$ & $\begin{array}{l}\text { Large doses of } \\
\text { digoxin may } \\
\text { be required. } \\
\text { Optimize } \\
\text { reduction of } \\
\text { fluid retention } \\
\text { before BB. }\end{array}$ & $\begin{array}{l}\text { BB like carvedilol } \\
\text { and nebivolol, as well } \\
\text { as ACEI/ARB are } \\
\text { contraindicated. }\end{array}$ \\
\hline
\end{tabular}

Abbreviations: $\mathrm{HF}_{\mathrm{r}} \mathrm{EF}$, heart failure with reduced ejection fraction; $\mathrm{HF} E F$, heart failure with increased ejection fraction; $\mathrm{BB}$, beta blockers; $\mathrm{ACEI}$, angiotensin receptor inhibitors; $A R B$, angiotensin receptor blockers; $\mathrm{HF}_{\mathrm{p}} \mathrm{EF}$, heart failure with preserved ejection fraction. 
of patients with thyrotoxicosis. The finding of LV-enhanced systolic and diastolic functions signify early echocardiographic detectable cardiac abnormalities in thyrotoxicosis, and the clinical management is with anti-thyroid drugs and $\beta$-adrenoceptor blockade. Diastolic dysfunction in thyrotoxicosis patients asymptomatic for cardiac disease should be treated with antithyroid drugs and $\beta$-adrenoceptor blockade.

Thyrocardiac patients with heart failure will require echocardiography to determine their ejection fraction, as this may influence a specific therapeutic regimen. A sound knowledge of clinical therapeutics and its application is indispensable in the use of anti-thyroid drugs, $\beta$-adrenoceptor blockade, diuretics, and digoxin, and in the management of thyrotoxicosis patients with heart failure who have increased, preserved, or reduced ejection fraction.

\section{Disclosure}

The authors have no conflicts of interest to disclose.

\section{References}

1. Gordon HW, Leonard SL, Ellen WS. The heart in endocrine and nutritional disorders. In: Braunwald E, editor. Heart Disease. 5th ed. Philadelphia; W B Saunders; 1997:1890-1894.

2. Weetman AP. Grave's disease 1835-2002. Horm Res. 2003;59 Suppl 1: $114-118$

3. Kahaly GJ, Dillmann WH. Thyroid hormone action in the heart. Endocrine Rev. 2005;26(5):704-728.

4. Kiss E, Jakab G, Kranias EG, Edes I. Thyroid hormone-induced alterations in phospholamban protein expression: regulatory effects on sarcoplasmic reticulum $\mathrm{Ca} 2+$ transport and myocardial relaxation. Circ Res. 1994;75(2):245-251.

5. Klein I, Ojamaa K. Thyroid hormone and the cardiovascular system. N Engl J Med. 2001;344(7):501-509.

6. Dillmann WH. Cellular action of thyroid hormone on the heart. Thyroid. 2002;12(6):447-452

7. Danzi S, Klein I. Thyroid hormone and the cardiovascular system. Minerva Endocrinol. 2004;29(3):139-150.

8. Ladenson PW, Sherman SI, Baughman KL, Ray PE, Feldman AM. Reversible alterations in myocardial gene expression in a young man with dilated cardiomyopathy and hypothyroidism. Proc Natl Acad Sci US A. 1992;89(12):5251-5255.

9. Lewicki JA, Protter AA. Physiological studies of the natriuretic peptide family. In: Laragh JH, Brenner BM, editors. Hypertension: Pathophysiology, Diagnosis and Management. New York: Raven Press; 1995:1029-1053.

10. Shi W, Wymore R, Yu H, et al. Distribution and prevalence of hyperpolarization-activated cation channel (HCN) mRNA expression in cardiac tissues. Circ Res. 1999;85(1):e1-e6.

11. Pachucki J, Burmeister LA, Larsen PR. Thyroid hormone regulates hyperpolarization-activated cyclic nucleotide-gated channel (HCN2) mRNA in the rat heart. Circ Res. 1999;85(6):498-503.

12. Hoit BD, Khoury SF, Shao Y, Gabel M, Ligget SB, Walsh RA. Effects of thyroid hormone on cardiac b-adrenergic responsiveness in conscious baboons. Circulation. 1997;96(2):592-598.

13. Levey GS. Catecholamine sensitivity, thyroid hormone and the heart. Am J Med. 1971;50:413-420.

14. Klein I. Endocrine disorders and cardiovascular disease. In: Zipes DP, Libby P, Bonow R, Braunwald E, editors. Braunwald's Heart Disease: A Textbook of Cardiovascular Medicine. 7th ed. Philadelphia: W.B. Saunders; 2005:2051-2065.
15. Ventrella SM, Klein I. Beta-adrenergic receptor blocking drugs in the management of hyperthyroidism. The Endocrinologist. 1994;4(5):391-399.

16. Levey GS, Klein I. Catecholamine-thyroid hormone interactions and the cardiovascular manifestations of hyperthyroidism. Am J Med. 1990; 88(6):642-646.

17. Coulombe P, Dussault JH, Walker P. Plasma catecholamine concentration in hyperthyroidism and hypothyroidism. Metabolism. 1976;25(9): 973-978.

18. Bayliss RI, Edwards OM. Urinary excretion of free catecholamines in Graves' disease. J Endocrinol. 1971;49(1):167-173.

19. Davis PJ, Davis FB. Nongenomic actions of thyroid hormone on the heart. Thyroid. 2002;12(6):459-466.

20. Hiroi Y, Kim HH, Ying H, et al. Rapid nongenomic actions of thyroid hormone. Proc Natl Acad Sci U S A. 2006;103(38):14104-14109.

21. Park KW, Dai HB, Ojamaa K, Lowenstein E, Klein I, Sellke FW. Direct vasomotor effect of thyroid hormones on rat skeletal muscle resistance arteries. Anesth Analg. 1997;85(4):734-738.

22. Napoli R, Biondi B, Guardasole V, et al. Impact of hyperthyroidism and its correction on vascular reactivity in humans. Circulation. 2001; 104(25):3076-3080.

23. Woeber KA. Thyrotoxicosis and the heart. N Engl J Med. 1992; 327:94-98.

24. Armigliato M, Paolini R, Aggio S, et al. Hyperthyroidism as a cause of pulmonary arterial hypertension: a prospective study. Angiology. 2006; 57(5):600-606.

25. Ichiki T. Thyroid hormone and atherosclerosis. Vascul Pharmacol. 2010;52(3-4):151-156.

26. World Health Organization [homepage on the Internet]. World Medical Association Declaration of Helsinki. Ethical Principles for Medical Research Involving Human Subjects. Bulletin of the World Health Organization; 2001. Available from: www.who.int/bulletin/ archives/79(4)373.pdf. Accessed October 15, 2014.

27. Ilercil A, O'Grady MJ, Roman MJ, et al. Reference values for echocardiographic measurements in urban and rural populations of differing ethnicity: the Strong Heart Study. J Am Soc Echocardiogr. 2001;14(6):601-611.

28. Syntron Bioresearch Inc. Laboratory Instruction Manuscript. Carlsbad, CA, USA. 1998; Catalog numbers, 1006-2210.

29. Feigenbaum H, editor. Echocardiography. 5th ed. Philadelphia: Lippincott Williams and Wilkins; 1994

30. Schiller NB, Shah PM, Crawford M, et al. Recommendations for quantification of the left ventricle by two-dimensional echocardiography. J Am Soc Echocardiogr. 1989;2(5):362-364.

31. Fazio S, Palmieri EA, Lombardi G, Biondi B. Effects of Thyroid Hormone on the Cardiovascular System. Recent Prog Horm Res. 2004; 59:31-50.

32. Mehta PA, Dubrey SW. High output heart failure. QJM. 2009;102(4): $235-241$.

33. Sangster JK, Panciera DL, Abbott JA. Cardiovascular Effects of Thyroid Disease. Compend Contin Educ Vet. 2013;35(7):E5.

34. Shapiro SM, Bersotin MM, Laks MM. In search of the Holy Grail: the study of diastolic ventricular functions by use of Doppler echocardiography. J Am Coll Cardiol. 1991;17(7):1517-1519.

35. Buccino RA, Spann JF Jr, Pool PE, Sonnenblick EH, Braunwald E. Influence of the thyroid state on the intrinsic contractile properties and the energy stores of the myocardium. J Clin Invest. 1967; 46(10):1669-1682.

36. Feldman T, Borow KM, Sarne DH, Neumann A, Lang RM. Myocardial mechanics in hyperthyroidism: importance of left ventricular loading conditions, heart rate and contractile state. $\mathrm{J} \mathrm{Am} \mathrm{Coll} \mathrm{Cardiol.}$ 1986;7(5):967-974.

37. Mintz G, Pizzarello R, Klein I. Enhanced left ventricular diastolic function in hyperthyroidism: noninvasive assessment and response to treatment. J Clin Endocrinol Metab. 1991;73(1):146-150.

38. Friedman MJ, Okada RD, Ewy GA, Hellman DJ. Left ventricular systolic and diastolic function in hyperthyroidism. Am Heart J. 1982;104(6): $1303-1308$.

39. Kral J, Hradec J, Limanova J. Heart in thyroid diseases. Cor Vasa. 1992; 34(2):108-114. 
40. Marcisz C, Kucharz EJ, Jonderko G, Wojewódka J. The Systolic function of the Left Ventricle of heart in patients with hyperthyroidism during therapy. Pol Arch Med Wewn. 2001;105(2):131-138.

41. Bond BR, Fox PR, Peterson ME, Skavaril RV. Echocardiographic findings in 103 cats with hyperthyroidism. J Am Vet Med Assoc. 1988; 192(11):1546-1549.

42. Merillon JP, Passa PH, Chastre J, Wolf A, Gourgon R. Left ventricular function and hyperthyroidism. Br Heart J. 1981;46(2):137-143.

43. Eber O, Buchinger W, Lindner W, et al. The effect of D-versus L-propranolol in the treatment of hyperthyroidism. Clin Endocrinol (Oxf). 1900;32(3):363-372.

44. Geffner DL, Hershman JM. $\beta$-adrenoceptor blockade in treatment of hyperthyroidism. Am J Med. 1992;93(1):61-68.

45. Aurigemma GP, Gottdiener JS, Shemanski L, Gardin J, Kitzman D. Predictive valve of systolic and diastolic function for incident congestive heart failure in the elderly: the cardiovascular health study. Am J Coll Cardiol. 2001;37(4):1042-1048.

46. Redfield MM, Jacobsen SJ, Burnett JC Jr, Mahoney DW, Bailey KR, Rodeheffer RJ. Burden of systolic and diastolic ventricular dysfunction in the community: appreciating the scope of the heart failure epidemic. JAMA. 2003;289(2):194-202.

47. Gaasch WH. Diagnosis and treatment of heart failure based on left ventricular systolic or diastolic dysfunction. JAMA. 1994;271(16): 1276-1280

48. Jing XC, Liu Y, Huang H. [Left ventricular diastolic function of patients with newly diagnosed hyperthyroidism]. Sichuan Da Xue Xue Bao Yi Xue Ban. 2012;43(3):462-466. Chinese.

49. Smit JW, Eustatia-Rutten CF, Corssmit EP, et al. Reversible Diastolic Dysfunction after Long-term exogenous subclinical hyperthyroidism: a randomized placebo-controlled study. J Clin Endocrinolol Metab. 2005;90(11):6041-6047.

50. Yue WS1, Chong BH, Zhang XH, et al. Hyperthyroidism-induced left ventricular diastolic dysfunction: implication in hyperthyroidism-related heart failure. Clin Endocrinol (Oxf). 2011;74(5):636-643.

51. Anand IS, Florea VG. High output cardiac failure. Curr Treat Options Cardiovasc Med. 2001;3(2):151-159.

52. Anakwue RC, Onwubere BJ, Anisiuba BC, Ikeh VO, Mbah A, Ike SO. Congestive heart failure in subjects with thyrotoxicosis in a black community. Vasc Health Risk Manag. 2010;6:473-477.

53. Kolawole BA, Balogun MO. Thyrotoxicosis and heart-a review of the literature. Niger J Med. 2001;10(2):50-54.

54. Danbauchi SS, Anumah FE, Alhassan MA, et al. Thyrocardiac Disease in Zaria: Clinical and Echocardiographic Characteristics. Echocardiography Journal. 2004;2:1-5.

55. Choudhury RP, MacDermot J. Heart failure in thyrotoxicosis, an approach to management. Br J Clin Pharmacol. 1998;46(5):421-424.

56. Ikram $\mathrm{H}$. The nature and prognosis of thyrotoxic heart disease. $Q J$ Med. 1985;54(213):19-28.

57. Levey GS, Klein I. Catecholamine-thyroid hormone interactions and the cardiovascular manifestations of hyperthyroidism. Am J Med. 1990;88(6):642-646.

58. Siu CW, Yeung CY, Lau CP, Kung AW, Tse HF. Incidence, clinical characteristics and outcome of congestive heart failure as the initial presentation in patients with primary hyperthyroidism. Heart. 2007; 93(4):483-487.

59. Niakara A, Bama A, Nebie LV. Signs and outcome of 61 cases of thyrotoxic heart disease. Trop Cardiol. 2004;30:118:24-27.

Therapeutics and Clinical Risk Management

\section{Publish your work in this journal}

Therapeutics and Clinical Risk Management is an international, peerreviewed journal of clinical therapeutics and risk management, focusing on concise rapid reporting of clinical studies in all therapeutic areas, outcomes, safety, and programs for the effective, safe, and sustained use of medicines. This journal is indexed on PubMed Central, CAS,
60. Osman F, Daykin J, Sheppard MC, Gammage MD, Frankln JA. Atrial fibrillation predicts mortality in thyrotoxicosis. British Endocrinology Society meeting 2002. Bioscientifica. 2002;275-278.

61. Huffman DH, Klaassen CD, Hartman CR. Digoxin in hyperthyroidism. Clin Pharmacol Ther. 1977;22(5 Pt 1):533-538.

62. Shenfield GM, Thompson J, Horn DB. Plasma and urinary digoxin in thyroid dysfunction. Eur J Clin Pharmacol. 1977;12(6):437-443.

63. Chaudhury S, Ismail-Beigi F, Gick GG, Levenson R, Edelman IS. Effect of thyroid hormone on the abundance of $\mathrm{Na}, \mathrm{K}$ adenosine triphosphatesubunit messenger ribonucleic acid. Mol Endocrinol. 1987;1(1): 83-89.

64. Ikram H. Haemodynamic effects of beta adrenergic blockade in hyperthyroid patients with and without heart failure. Br Med J. 1977; 1(6075):1505-1507.

65. Packer M, Coats AJ, Fowler MB, et al. Effect of Carvedilol on Survival in Severe Chronic Heart Failure. N Engl J Med. 2001;344(22): 1651-1658.

66. No authors listed. Effects of Metoprolol CR/XL in chronic heart failure: Metoprolol CR/XL randomised Intervention Trial in Congestive Heart Failure (MERIT-HF). Lancet. 1999;353(9169):2001-2007.

67. No authors listed. The Cardiac Insufficiency Bisoprolol Study II (CIBIS-II): a randomised trial. Lancet. 1999;353(9146):9-13.

68. Isley WL, Dahl S, Gibbs H. Use of esmolol in managing a thyrotoxic patient needing emergency surgery. Am J Med. 1990;89(1):122-123.

69. Rubenfeld S, Silverman VE, Welch KM, Mallette LE, Kohler PO. Variable plasma propranolol levels in thyrotoxicosis. $N$ Engl J Med. 1979;300(7):353-354.

70. Routledge PA, Shand DG. Clinical pharmacokinetics of propranolol. Clin Pharmacokinet. 1979;4(2):73-90.

71. Geffner DL, Sladek J, Hershman JM. Pharmacokinetics and clinical effects of atenolol therapy of hyperthyroidism. Drugs Exp Clin Res. 1990;16(4):167-173.

72. Biondi B, Palmieri EA, Lombardi G, Fazio S. Effects of thyroid hormone on cardiac function: the relative importance of heart rate, loading conditions, and myocardial contractility in the regulation of cardiac performance in human hyperthyroidism. J Clin Endocrinol Metab. 2002;87(3):968-974.

73. Donatelli M, Assennato P, Abbadi V, et al. Cardiac changes in subclinical and overt hyperthyroid women: retrospective study. Int J Cardiol. 2003;90(2-3):159-164.

74. Ching GW, Franklyn JA, Stallard TJ, et al. Cardiac hypertrophy as a result of long term thyroxine therapy and thyrotoxicosis. Heart. 1996; 75(4):363-368

75. Dorr M, Wolff B, Robinson DM, et al. The association of thyroid function with cardiac mass and left ventricular hypertrophy. $J$ Clin Endocrinol Metab. 2005;90(2):673-677.

76. Klein I, Levey GS. The cardiovascular system in thyrotoxicosis. In: Braverman LE, Utiger RD, editors. Werner and Ingbar's The Thyroid: a Fundamental and clinical Text, 8th ed. Philadelphia: Lippincott Williams and Wilkins; 2000:596-604.

77. Umpierrez GE, Challapalli S, Patterson C. Congestive heart failure due to reversible cardiomyopathy in patients with hyperthyroidism. Am J Med Sci. 1995;310(3):99-102.

78. Riaz K, Forker AD, Isley WL, Hamburg MS, McCullough PA. Hyperthyroidism: a curable cause of congestive heart failure-three case reports and a review of literature. Congest Heart Fail. 2003;9(1):40-46.

EMBase, Scopus and the Elsevier Bibliographic databases. The manuscript management system is completely online and includes a very quick and fair peer-review system, which is all easy to use. Visit http://www.dovepress.com/testimonials.php to read real quotes from published authors. 